\title{
GRA1 protein vaccine confers better immune response compared to codon-optimized GRA1 DNA vaccine
}

\author{
Mert Döşkaya $^{\mathrm{a}, \mathrm{h}}$, Mina Kalantari-Dehaghi ${ }^{\mathrm{b}}$, Craig M. Walsh ${ }^{\mathrm{b}}$, Elżbieta Hiszczyńska-Sawicka ${ }^{\mathrm{c}}$, \\ D. Huw Davies ${ }^{d}$, Philip L. Felgner ${ }^{d}$, Liza S.Z. Larsen ${ }^{e}$, Richard H. Lathrop ${ }^{\text {f,g }}$, \\ G. Wesley Hatfield ${ }^{\mathrm{e}, \mathrm{g}}$, Jessica R. Schulz ${ }^{\mathrm{b}}$, Yüksel Gürüz ${ }^{\mathrm{h}}$, Frances Jurnak ${ }^{\mathrm{a}, *}$ \\ ${ }^{a}$ Department of Physiology and Biophysics, University of California, Irvine, CA, USA \\ ${ }^{\mathrm{b}}$ Department of Molecular Biology \& Biochemistry, Irvine, CA, USA \\ ${ }^{c}$ Department of Microbiology, Gdansk University of Technology, Poland \\ ${ }^{d}$ Center for Virus Research, Department of Molecular Biology and Biochemistry, University of California, Irvine, CA, USA \\ e Department of Microbiology \& Molecular Genetics, University of California, Irvine, CA, USA \\ ${ }^{\mathrm{f}}$ Department of Computer Science, University of California, Irvine, CA, USA \\ g CODA Genomics Inc., Aliso Viejo, CA, USA \\ ${ }^{\mathrm{h}}$ Department of Parasitology, Ege University Medical School, Turkey
}

Received 26 September 2006; received in revised form 26 October 2006; accepted 30 October 2006 Available online 20 November 2006

\begin{abstract}
The present study evaluates immunogenicity and protection potency of a codon-optimized GRA1 DNA vaccine, wild type GRA1 DNA vaccine and an adjuvanted recombinant GRA1 protein vaccine candidate in BALB/c mice against lethal toxoplasmosis. Of the three GRA1 vaccines tested, the recombinant GRA1 protein vaccine results reveal significant increase in immune response and prolonged survival against acute toxoplasmosis compared to DNA vaccinations. Immune response and protection conferred by codon-optimized GRA1 DNA vaccine was slightly better than wild type GRA1 DNA vaccine.
\end{abstract}

(C) 2006 Elsevier Ltd. All rights reserved.

Keywords: Toxoplasma gondii; GRA1; Codon-optimization; DNA vaccination; Adjuvanted recombinant protein vaccination

\section{Introduction}

Toxoplasma gondii is one of the most successful protozoan parasites because it has a very broad host range, infecting all warm-blooded animals, including humans [1] and causes serious clinical presentations. There is no $100 \%$ effective drug to treat all clinical presentations of $T$. gondii. Available drugs have many side effects and reactivation may occur any time. The development of a vaccine, which can prevent the consequences of acute infection, is therefore, an attractive

\footnotetext{
* Corresponding author at: Department of Physiology and Biophysics, College of Medicine, Rm. 346D Medical Science I, University of California, Irvine CA 92697, USA. Tel.: +1 949824 6623; fax: +1 9498248540 .

E-mail address: jurnak@uci.edu (F. Jurnak).
}

alternative. After classification in category B bioterrorism agents as a food and water safety threat, the demand for a protective vaccine has increased [2].

Vaccine strategies against toxoplasmosis aim to induce Th1 response and IFN- $\gamma$ production because immune protection against $T$. gondii in mice is primarily correlated with Th1 cell mediated immunity $[3,4]$ and IFN- $\gamma$ secretion [5]. Many attempts have been made to create an immunogenic protective vaccine against toxoplasmosis using mutant $T$. gondii strains, purified proteins, and DNA vaccines since 1990s [6]. The accumulated results suggest that a protective vaccine against T. gondii infection is feasible. Recombinant protein vaccines and DNA vaccines using Surface Antigen 1 (SAG1), SAG2, Dense Granule Antigen 1 (GRA1), GRA4, GRA7, Rhoptry Protein 2 (ROP2), Microneme Protein 3 (MIC3) and Heat 
Shock Protein 70 (HSP70) elicit partial, full, or occasionally no protection in animals depending on the virulence of the $T$. gondii strains [7-30]. Of all the vaccine candidates against toxoplasmosis, GRA1 appears to be an immunogenic promising vaccine candidate [8,26-28,31]. Existing GRA1 vaccination trials used recombinant protein or DNA vaccines. Although immune response and protection potency have been investigated in detail about GRA1 DNA vaccination $[26,28]$, the cellular immune response and protection potency of an adjuvanted recombinant GRA1 protein vaccine haven't been evaluated in mice yet $[8,27,31]$. Taken together, the experimental studies using various GRA1-derived vaccines are encouraging, however much work remains to put together the pieces of the puzzle, i.e. highlight the complexity of the immune response and the unpredictable relationships among various parameters such as vaccine strategy to be used against toxoplasmosis, protection and cellular immune response elicited by recombinant protein vaccine or parasite strain used to challenge the mice. In order to comprehensively evaluate these variables, the present study compares cellular immune response and protection potency of a recombinant GRA1 protein vaccine adjuvanted with a strong Th1 inducer Provax [32,33], a wild type GRA1 DNA vaccine and a GRA1 DNA vaccine codon-optimized for protein expression in mammalian cells. Codon usage optimization is widely accepted as a means of increasing the level of in vivo antigen expression from DNA vaccines and improving the cellular and humoral immune responses against the expressed antigens from diverse microorganisms [34-47]. The codonoptimized GRA1 DNA vaccine used in this study is the first example of a codon-optimized gene being used as DNA vaccine candidate against $T$. gondii.

\section{Materials and methods}

Unless noted otherwise, all reagents were purchased from Sigma-Aldrich Corporation (St. Louis, MO, USA).

\subsection{Mice}

Female 6 week-old BALB/c mice were purchased from Charles River Laboratories Inc. (Wilmington, MA). Mice were housed and fed under standard, suitable conformist conditions. The experimental plan was performed under the instructions and approval of the Institutional Animal Care and Use Committee of UCI for animal ethics.

\subsection{Parasites and preparation of T. gondii antigen}

T. gondii RH strain tachyzoites were used to challenge the immunized mice and to prepare $T$. gondii antigen. RH strain tachyzoites were maintained in confluent monolayers of human foreskin fibroblasts (HFF) cell culture grown in Dulbeccos modified Eagle medium (DMEM) supplemented with $10 \%(\mathrm{v} / \mathrm{v})$ heat inactivated fetal bovine serum (Hyclone,
Logan, UT), $2 \mathrm{mM}$ L-glutamine and $50 \mathrm{mg}$ gentamycin per $\mathrm{ml}$ (Invitrogen-Gibco, Carlsbad, CA). T. gondii antigen (TAg) was prepared with the RH strain tachyzoites obtained from HFF cell culture as described [12].

\subsection{Computationally optimized DNA assembly (CODA) of the GRAl gene}

The GRA1 protein sequence from amino acid positions 25-190, excluding the signal peptide, was obtained from GENBANK database (accession number M26007), and submitted to CODA at the Computational Biology Research (CBR) Laboratory of the UC Irvine Institute for Genomics and Bioinformatics. The CODA algorithm generated a list of 36 linearly overlapping and abutting oligonucleotides, 39-64 nucleotides (nts) in length, optimized for self-assembly and expression of the codon-optimized GRA1 gene (co-GRA1) in mammalian cells. These oligonucleotides were purchased from Integrated DNA Technologies (Coralville, IA, USA).

\subsubsection{Assembly of co-GRA1 intermediate DNA fragments}

The full-length co-GRA1 DNA sequence was divided into three partially overlapping intermediate DNA fragments, each of which was subdivided into 12 short overlapping and abutting DNA oligonucleotides (intermediate fragment $0: 237 \mathrm{bp}$; intermediate fragment 1:196 bp; intermediate fragment 2:196 bp). The co-GRA1 gene was assembled in two steps in which the DNA oligonucleotides were assembled first to form the three intermediate DNA fragments and then the intermediated fragments were mixed to form the full-length gene. For the assembly of each of the three intermediate DNA fragments of GRA1, the constituent DNA oligonucleotide set was added to a primer extension reaction at a final concentration of $0.1 \mu \mathrm{M}$ along with an excess $(0.5 \mu \mathrm{M})$ of leader and trailer primer oligonucleotides (the most $5^{\prime}$ - and $3^{\prime}$ distant DNA oligonucleotides). The reactions included $2.5 \mathrm{U}$ of $P f u$ Ultra High-Fidelity DNA polymerase (Stratagene, La Jolla, CA), $300 \mu \mathrm{M}$ dNTPs, and $1 \times P f u$ Ultra reaction buffer. The primer extension and PCR amplification reactions were performed in an Eppendorf Mastercycler (Hamburg, Germany) using the following calculated-control protocol: $5 \mathrm{~min}$ initial denaturation step at $95^{\circ} \mathrm{C}$, followed by 25 cycles of $20 \mathrm{~s}$ at $95^{\circ} \mathrm{C}, 30 \mathrm{~s}$ at $62^{\circ} \mathrm{C}$, and $1 \mathrm{~min}$ at $72^{\circ} \mathrm{C}$, and an extension of $5 \mathrm{~min}$ at $72^{\circ} \mathrm{C}$. The PCR products were visualized by agarose gel electrophoresis.

\subsubsection{TOPO PCR cloning}

PCR product of each intermediate DNA fragment of the GRA1 gene was cloned into a pCRII-Blunt-TOPO vector according to the manufacturer's recommended protocol using One Shot electrocompetent Top 10 Escherichia coli cells (Invitrogen, Carlsbad, CA). The resulting plasmids, which contained intermediate DNA fragments of the correct size were visualized by agarose gel electrophoresis and purified for DNA sequencing using a plasmid mini purification kit 
according to the manufacturer's protocol (Aurum, Bio-Rad, Hercules, CA).

\subsubsection{PCR assembly of full length co-GRAI}

One of each sequence-verified intermediate DNA fragment of the GRA1 gene was isolated from the pCR-Blunt II TOPO vector by PCR amplification using the most $5^{\prime}$ and $3^{\prime}$-distant oligonucleotides for each intermediate DNA fragment. The amplification reactions included an excess of $0.25 \mu \mathrm{M}$ of leader and trailers, $2.5 \mathrm{U}$ of PfuUltra HighFidelity DNA polymerase (Stratagene), $150 \mu \mathrm{M}$ dNTPs, and $1 \times P f u$ Ultra reaction buffer. The PCR amplification reactions were performed using the following calculated-control protocol: 5 min initial denaturation step at $95^{\circ} \mathrm{C}$, followed by 25 cycles of $20 \mathrm{~s}$ at $95^{\circ} \mathrm{C}, 1 \mathrm{~min}$ at $68^{\circ} \mathrm{C}$, and $1 \mathrm{~min}$ at $72{ }^{\circ} \mathrm{C}$, and a final extension of $5 \mathrm{~min}$ at $72^{\circ} \mathrm{C}$. Subsequently, $1 \mu l$ of each intermediate DNA fragment PCR product was combined with $1 \mu \mathrm{M}$ GRA1 gene leader $\left(5^{\prime}\right.$ - most distant oligonucleotide of $45 \mathrm{nts}$ and $1 \mu \mathrm{M}$ gene trailer (the $3^{\prime}$ - most distant oligonucleotide of $44 \mathrm{nts}$ ) in another primer extension, using the same PCR amplification reaction defined above to generate the full-length co-GRA1 gene $(531 \mathrm{bp})$. The PCR product visualization, TOPO PCR cloning and plasmid purification for DNA sequencing of the full-length co-GRA1 gene were performed as described above.

\subsection{Cloning of wt-GRAl and co-GRAl into a mammalian expression vector}

A cytomegalovirus (CMV) promoter containing mammalian expression vector $(10 \mu \mathrm{g} ; 5.1 \mathrm{~kb}$; kanamycin resistant; Gene Therapy Systems, San Diego, CA) was linearized by BamHI as described [48]. The following primers were designed to generate a linear acceptor vector with sequences suitable for cloning by homologous recombination, $5^{\prime}$-CACCATCACCATCACCATCACCATCACGTCGAC- $3^{\prime}$ (forward primer, $33 \mathrm{nt}$ ), and 3'-TGATCTTTTATTAGCCAGAAGTGATCTGGATCC-5' (reverse primer, $33 \mathrm{nt}$ ). During the PCR reaction an $\mathrm{N}$-terminal polyhistidine tag was introduced to CMV vector immediately after the start codon, which was fused in frame with the ORF for purification and detection purposes. The linear acceptor vector was amplified as described [48]. The resulting linear CMV vector was used for in vivo recombination cloning.

\subsubsection{PCR amplification of $w t-G R A 1$ and co-GRA1}

Wt-GRA1 and co-GRA1 were isolated from their recombinant plasmids with primers designed to incorporate adapter termini into the PCR product to facilitate directional cloning by homologous recombination ('HiRec') into the CMV vector. The primers for the wild type GRA1 were $5^{\prime}-\mathrm{CA}$ CCATCACCATCACCATCACCATCACGTCGACGCCGAAGGCGGCGACAACCA-3' (forward primer, $53 \mathrm{nt}$; overlapping sequences, underlined) and $3^{\prime}$-TGATCTTTTATTAGCCAGAAGTGAT CTGGATCCCTCTCTCTCTCCTGTTAGGA-5' (reverse primer, $56 \mathrm{nt}$; overlapping sequences, underlined). The primers for co-GRA1 were 5 -CACCATCACCATCACCATCACCATCACGTCGACGCAGAGGGAGGCGACAACCA-3' (forward primer, $53 \mathrm{nt}$; overlapping sequences, underlined) and $3^{\prime}$-TGATCTTTTATTAGCCAGAAGTGATCTGGATCCCTCCCTCTCGCCGGTCAGGA-5' (reverse primer, $56 \mathrm{nt}$; overlapping sequences, underlined). Co-GRA1 and wt-GRA1 genes were isolated from their template plasmids using the designed primers $(0.5 \mu \mathrm{M}$ each), $2 \mathrm{U}$ of TaqDNA polymerase (Fisher Scientific), $150 \mu \mathrm{M}$ dNTPs and $1 \times$ TaqDNA polymerase reaction buffer with the following calculated PCR protocol; $5 \mathrm{~min}$ initial denaturation step at $95^{\circ} \mathrm{C}$, followed by 30 cycles of $0.5 \mathrm{~min}$ at $95^{\circ} \mathrm{C}, 0.5 \mathrm{~min}$ at $50^{\circ} \mathrm{C}$, and $3.5 \mathrm{~min}$ at $72^{\circ} \mathrm{C}$, and a final extension of $10 \mathrm{~min}$ at $72^{\circ} \mathrm{C}$. The PCR products were visualized by agarose gel electrophoresis, purified using a PCR purification kit (Qiagen) according to the manufacturer's protocol, and quantified by spectrophotometry.

\subsubsection{In vivo recombination cloning method}

In vivo recombination cloning was performed as described [48]. Briefly, the linear CMV vector, purified PCR product, and DH5 $\alpha$ competent cells were mixed and heat shocked. Plasmids from overnight culture were purified using plasmid mini purification kit according to the manufacturer's protocol (Aurum, Bio-Rad) and visualized by agarose gel electrophoresis. The resulting plasmids containing wt-GRA1 and co-GRA1 were named CMV/wt-GRA1 and CMV/coGRA1, respectively.

\subsection{In vitro transfection of human embryonic kidney cells}

Human embryonic kidney (HEK) 293 mammalian cells were obtained from the American Type Culture Collection (ATCC number: CRL-1573, Manassas, VA). HEK 293 cells were maintained in Dulbecco's modified eagle medium (DMEM), supplemented with $10 \%(\mathrm{v} / \mathrm{v})$ heat-inactivated fetal bovine serum, $2 \mathrm{mM}$ L-glutamine, $100 \mathrm{IU}$ of penicillin per $\mathrm{ml}$, and $100 \mathrm{~g}$ of streptomycin per $\mathrm{ml}$ (Invitrogen-Gibco) at $5 \% \mathrm{CO}_{2}$ and $37^{\circ} \mathrm{C}$. Then HEK 293 cells were transfected with CMV/wt-GRA1 and CMV/co-GRA1 using Lipofectamine 2000 reagent according to the manufacturer's protocol (Invitrogen). HEK 293 cells transfected in four-well chamber slides were observed using monoclonal anti-polyhistidine antibody and immunofluorescence microscopy to determine the level of protein expression. In addition, the same HEK 293 cells, which were transfected in $10 \mathrm{~cm}$-diameter culture dishes with the same protocol, were lysed to compare the protein expression using monoclonal anti-polyhistidine antibody and Western blotting.

\subsection{Immunofluorescence}

HEK 293 cells transfected with CMV/wt-GRA1 or CMV/co-GRA1 plasmid in four-well chamber slides fixed 
with methanol and acetone and incubated with $1 \%$ BSA (diluted in $1 \times$ PBS) (Sigma-Aldrich, St. Louis, MO). The slides were then probed with the monoclonal antipolyhistidine antibody (Sigma) with a dilution of 1:200 for $1 \mathrm{~h}$ at room temperature, washed and then probed with antimouse IgG antibody conjugated with FITC produced in sheep (clone, His-1; Sigma) with a dilution of 1:500 for $1 \mathrm{~h}$ at room temperature. Thereafter, slides were washed and visualized using an immunofluorescence microscope (Zeiss Axiomat, Thornwood, NY).

\subsection{Sodium dodecyl sulfate-polyacrylamide gels and Western blotting}

HEK 293 cells, transfected with CMV/wt-GRA1 and CMV/co-GRA1 obtained from $10 \mathrm{~cm}$-diameter culture dishes, were scraped from the dishes and counted with a hemocytometer. Equal amount of cells (approximately $6 \times 10^{6}$ cell per each sample) were washed thrice with $1 \times$ PBS followed by several cycles of freezing and thawing. The lysate of cells were centrifuged at $10,000 \times g$ for $10 \mathrm{~min}$. The amount of protein in the supernatant was determined using Coomassie Plus Protein Assay Reagent kit according to the manufacturer's protocol (Pierce, Rockford, Ill, USA). Serially diluted bovine serum albumin (BSA) was used as the reference. To compare the expression levels of CMV/wt-GRA1 and CMV/co-GRA1 in HEK 293 cell lysate, an equal amount of protein (approximately, $500 \mu \mathrm{g}$ protein per each sample) was separated by $12 \%$ sodium dodecyl sulfate-polyacrylamide gel (SDS-PAGE). To detect the immunoreactivity of the vaccine-induced antibodies, TAg was separated with $12 \%$ SDS-PAGE gel. The separated protein was transferred to a polyvinylidene difluoride (PVDF) transfer membrane (Immobilon-P, Millipore, Billerica, MA) and the membranes, which contained HEK 293 cell lysate, were probed with a 1:1000 dilution of the monoclonal anti-polyhistidine antibody (Sigma). To detect the immunoreactivity, the TAg-containing membranes were probed with 1:100 dilutions of four different serum sample pools, collected from three groups of vaccinated mice and control groups. Then the membranes were probed with a 1:1000 dilution of alkaline phosphatase-conjugated goat anti-mouse IgG $(\mathrm{H}+\mathrm{L})$ antibody (Bio-Rad). Thereafter, the blot was developed with 5-bromo-4-chloro-3-indolyl phosphate (BCIP) and Nitro-BT (Fisher Scientific) diluted in alkaline phosphatasedeveloping buffer $\left(0.1 \mathrm{M} \mathrm{Na}_{2} \mathrm{CO}_{3}, \mathrm{pH} 9.5,0.1 \mathrm{M} \mathrm{NaCl}, 5 \mathrm{mM}\right.$ $\mathrm{MgCl}_{2}$ ).

\subsection{Protein expression and purification}

E. coli Rosetta $^{\mathrm{TM}}$ 2(DE3) pLysS chemically competent cells (Novagen, San Diego, CA) were transformed with pUET $\Delta$ GRA1 [49] and grown in 11 LB supplemented with $100 \mu \mathrm{g} / \mathrm{ml}$ ampicillin and $50 \mu \mathrm{g} / \mathrm{ml}$ chloramphenicol with vigorous shaking at $37^{\circ} \mathrm{C}$ up to an optical density of 0.4 , calculated at $600 \mathrm{~nm}$. Then, the cells were induced with isopropyl- $\beta$-D-thiogalactopyranoside (IPTG) to a final concentration of $1 \mathrm{mM}$ with vigorous shaking at $20^{\circ} \mathrm{C}$ overnight. The cells were centrifuged at $5000 \times g$ and the pellet was resuspended with $50 \mathrm{ml}$ pre-chilled loading buffer $(50 \mathrm{mM}$ Tris-Cl pH: 7.5, $0.3 \mathrm{M} \mathrm{NaCl}$ and $0.5 \mathrm{mM} \mathrm{CaCl}_{2}$ ). Then, the cells were disrupted with an $\mathrm{M}-110 \mathrm{~L}$ microfluidizer processor (Microfluidics Corporation, Newton, MA) at a low temperature under internal pressure of $18,000 \mathrm{psi}$. The processed sample was centrifuged at $30,000 \times \mathrm{g}$ for $1 \mathrm{~h}$ at $4{ }^{\circ} \mathrm{C}$. The clarified supernatant was filtered through $0.45 \mu \mathrm{m}$ filter (Nalgene, Rochester, NY). Purification of the protein was performed by ÄKTA FPLC, a liquid chromatography system, which is controlled by UNICORN ${ }^{\mathrm{TM}}$ software, using a $5 \mathrm{ml}$ HiTrap Chelating HP column (Amersham Biosciences, Pittsburgh, PA). Clarified supernatant was applied to the HiTrap column with loading buffer. Then, the column was washed with $100 \mathrm{mM}$ imidazole containing $50 \mathrm{mM}$ Tris-Cl, $\mathrm{pH} 7.5$, $0.3 \mathrm{M} \mathrm{NaCl}$, and $0.5 \mathrm{mM} \mathrm{CaCl}_{2}$ buffer overnight at $4{ }^{\circ} \mathrm{C}$. The recombinant GRA1 (rGRA1) protein was eluted by raising the imidazole concentration to $500 \mathrm{mM}$. The protein fractions were detected by UV280, confirmed by $12 \%$ SDS-PAGE, pooled, and concentrated with an Ultrafree-MC Centrifugal Filter Units (Millipore) at $4{ }^{\circ} \mathrm{C}$. The protein was further purified by FPLC on a Superdex 200 column to remove excess endotoxin. The subsequent protein fractions were pooled, concentrated and quantitated. The molecular size of purified GRA1 protein was determined by matrix-assisted laser desorption ionization-time of flight (MALDI-TOF) mass spectrometry (MS) (Applied Biosystems, Foster City, CA) using a sinapinic acid matrix. Three purified protein samples from three different preparations were analyzed.

\subsection{Depletion and determination of endotoxin from purified protein}

Detoxi-gel affinity column, which contains immobilized Polymyxin B, was used to remove endotoxin from the purified GRA1 protein sample according to the manufacturer's protocol (Pierce). The amount of endotoxin in the eluted sample was determined with a Limulus Ameobocyte Lysate Gel-Clot test using Pyrotell single test vials according to the manufacturer protocol (Associates of Cape Cod, East Falmouth, MA). The concentration of endotoxin-depleted, purified rGRA1 samples were calculated as described above and stored at $-80^{\circ} \mathrm{C}$.

\subsection{Vaccination and challenge}

Three groups of female, 6 week-old, BALB/c mice (eight per each group) were vaccinated twice at three weeks interval with CMV/wt-GRA1, CMV/co-GRA1, and rGRA1 protein with PROVAX ${ }^{\mathrm{TM}}$ adjuvant (rGRA1-Provax). The plasmids were purified using an endol-free plasmid purification kit (EndoFree, Qiagen). During DNA vaccinations, $100 \mu \mathrm{g}$ plasmid was injected into both tibialis anterior muscle of anesthetized mice. 
The rGRA1-Provax vaccine was formulated using rGRA1 protein and Provax adjuvant. Provax was prepared as described using Tween-80, pluronic L121 and squalane [50]. To evaluate the efficacy of rGRA1-Provax vaccine five mice were vaccinated intraperitoneally with $33 \mu \mathrm{g}$ of only rGRA1 protein as a control group.

Negative controls were composed of three groups of animals (eight per each) vaccinated with $100 \mu \mathrm{g}$ empty vector and $33 \mu \mathrm{l}$ of stabilized Provax emulsion. A group of naïve mice was also used as a control to evaluate the GRA1 vaccinations during the measurement of antigen specific proliferative response and cytokine determination. Tail bleeds were performed three weeks after each vaccination. Eight mice from each group were challenged intraperitoneally with $1 \times 10^{5}$ viable $T$. gondii $\mathrm{RH}$ strain tachyzoites nine weeks after the prime vaccination.

\subsection{Measurement of humoral antibody response using protein microarray analysis}

Protein microarray chips were prepared as described [48,51]. Briefly, $15 \mu l$ purified rGRA1 $(2.5 \mathrm{mg} / \mathrm{ml})$ printed onto nitrocellulose-coated FAST ${ }^{\mathrm{TM}}$ glass slides (Schleicher \& Schuell, Keene, NH) using an OmniGrid 100 microarray printer (Genomics Solutions, Ann Arbor, MI). The slides were probed with mouse serum samples diluted in Protein Array Blocking Buffer (PABB, Schleicher \& Schuell) which were obtained three weeks after the first and second vaccinations. Proteome slides were washed with $1 \times$ TBS-T buffer $(0.5 \%$ Tween-20, $20 \mathrm{mM}$ Tris- $\mathrm{HCl}, 0.5 \mathrm{M} \mathrm{NaCl})$ and complexed antibodies were visualized after incubating the slides with $\mathrm{Cy} 3$-conjugated IgG antibody (Jackson ImmunoResearch, West Grove, PA). The proteome slides were washed with $1 \times$ TBS-T and $1 \times$ TBS buffers before scanning in a ScanArray 4000 laser confocal scanner (GSI Lumonics, Billerica, MA). The fluorescence intensity (FI) of each spot was quantified using QuantArray software (GSI Lumonics). Samples were considered positive if the FI of the 1/50-diluted vaccinated animal serum sample exceeded the FI +5 S.D. of the 1/50-diluted serum sample of the animal injected with the corresponding negative control for the particular group of vaccination.

\subsection{Determination of $\operatorname{Ig} G$ subclass antibody response using protein microarray analysis}

Analysis of serum anti-rGRA1 IgG1 and IgG2a subclass antibodies in vaccinated mouse serum samples were performed by protein microarray analysis as described above. After the slides were probed with 1/50-diluted mouse serum samples, the slides were incubated with $\mathrm{Cy} 3$-conjugated IgG1 and IgG2a antibody (Jackson ImmunoResearch) at $1 / 200$ dilution for $2 \mathrm{~h}$. Fluorescence intensities were analyzed using ScanArray 4000 laser confocal scanner and QuantArray software (GSI Lumonics) as described above.

\subsection{Measurement of antigen-specific proliferative immune response}

Nine weeks after the prime vaccination, spleens were surgically removed from euthanized mice (three mice per group). Single-cell suspensions of splenocytes were prepared as described [28]. Aliquots of $5 \times 10^{5}$ viable splenocytes in $100 \mu$ l growth medium $[1 \times$ RPMI 1640 supplemented with $10 \%$ FCS, $55 \mu \mathrm{M}$ 2-mercaptoethanol (Invitrogen-Gibco), $1 \mathrm{mM}$ sodium pyruvate, $0.1 \mathrm{mM}$ MEM non-essential amino acid, $2 \mathrm{mM}$ L-glutamine, penicillin $(100 \mathrm{U} / \mathrm{ml})$ and streptomycin $(100 \mu \mathrm{g} / \mathrm{ml})$ (Cellgro)] were plated in triplicate into each well of 96 well round bottom plate. Before the stimulation of spleen cells, endotoxin-depleted purified rGRA1 was incubated with polymyxin $\mathrm{B}$ to a final concentration of $50 \mu \mathrm{g} / \mathrm{ml}$ for $1 / 2 \mathrm{~h}$. Cells were stimulated with $0.6-50 \mu \mathrm{g} / \mathrm{ml}$ purified rGRA1 protein or stimulated with a concentration of $15 \mu \mathrm{g} / \mathrm{ml}$ unrelated vaccinia virus recombinant H3L (rH3L) control protein. As a positive control in all experiments, cells were incubated with Concanavalin A at a final concentration of $10 \mu \mathrm{g} / \mathrm{ml}$. As a negative control, only $200 \mu \mathrm{l}$ growth medium was used. Cultures of cells in a final volume of $200 \mu \mathrm{l}$ in each well were incubated $72 \mathrm{~h}$ at $5 \% \mathrm{CO}_{2}$ and $37^{\circ} \mathrm{C}$ and then pulsed with $1 \mu \mathrm{Ci}$ of ${ }^{3}[\mathrm{H}]$-thymidine (Perkin Elmer Life and Analytical Sciences, Boston, MA) per well, diluted in $50 \mu \mathrm{l}$ growth medium, during the last $16 \mathrm{~h}$. Cells were harvested using a cell harvester (TOMTEC, manual harvester 96, Mac IIM, Hamden, CT) and glass filter paper (Wallac, Turku, Finland). The radioactivity was quantified by liquid scintillation counting (BETA plate liquid scintillation counter (Wallac). The results are expressed as the stimulation index (SI), which is calculated as the mean counts per minute (cpm) of cells stimulated with rGRA1 protein divided by the mean cpm of controls.

\subsection{Cytokine determination}

Splenocytes were prepared as described above. Cell-free supernatant was collected and assayed for IL-4 activity at 24 and $72 \mathrm{~h}$ and gamma interferon (IFN- $\gamma$ ) activity at $72 \mathrm{~h}$. The concentration of IL-4 and IFN- $\gamma$ were determined using ELISA kits (eBioscience, San Diego, CA) according to the manufacturer protocol. The sensitivity limit for the ELISA was deduced from the standard curves after serial dilution of the recombinant mouse IFN- $\gamma$ and recombinant mouse IL-4 standards provided by the kit. Values higher than $100 \mathrm{pg} / \mathrm{ml}$ and $10 \mathrm{pg} / \mathrm{ml}$, calculated from the results with naïve mice, were considered positive for IFN- $\gamma$ and IL-4, respectively.

\subsection{Statistical analysis}

Data obtained during the study were processed using Prism 3.03 (GraphPad, San Diego, CA). A two-tailed unpaired $t$-test or one-way analysis of variance with $95 \%$ confidence interval was used to determine the significance between the vaccination groups. Kaplan-Meier survival 
curves were constructed to illustrate protection from lethal toxoplasmosis. Results of humoral immune response, cellular immune response and survival time were expressed as mean \pm standard deviation (S.D.).

\section{Results}

\subsection{PCR assembly of co-GRA1 and in vivo recombination cloning}

Wild type GRA1, without the signal peptide, is $498 \mathrm{bp}$ in length and has a $52 \% \mathrm{G} / \mathrm{C}$ content. To optimize the GRA1 gene for expression in mammalian cells, 19 codons were excluded, six codons were reduced in frequency, and $23.1 \%$ of the codons were changed (Table 1). The final co-GRA1 gene has a $63 \% \mathrm{G} / \mathrm{C}$ content. The codon usage of Homo sapiens was used to measure the codon adaptation index (CAI) of wt-GRA1 and co-GRA1 codons. The CAI of wt-GRA1 is 0.697 and the CAI of co-GRA1 is 0.917 .

The self-assembly of the co-GRA1 gene was performed with two PCR and TOPO cloning reactions. The primer extension and PCR amplification products of the over lapping CODA-designed DNA oligonucleotides to produce the $237 \mathrm{bp}$, and two $196 \mathrm{bp}$, product intermediate gene fragments are shown in Fig. 1, lanes 2-4, respectively. The 531 bp, fulllength, co-GRA1 primer extension and PCR product of these three over-lapping intermediate gene fragments is shown in Fig. 1, lane 1. Then, wt-GRA1 and co-GRA1 were isolated from pUET $\triangle$ GRA 1 and pCR-Blunt II TOPO vectors, respectively and rapidly cloned into the CMV vector. The resulting kanamycin-resistant $E$. coli cell clones contained either the CMV/wt-GRA1 plasmid with the directionally inserted inframe wt-GRA1 gene or the CMV/co-GRA1 plasmid with the co-GRA1 gene.

\subsection{In vitro transfection studies}

To determine the in vitro protein expression levels of co-GRA1 and wt-GRA1 in mammalian cells, human embry-

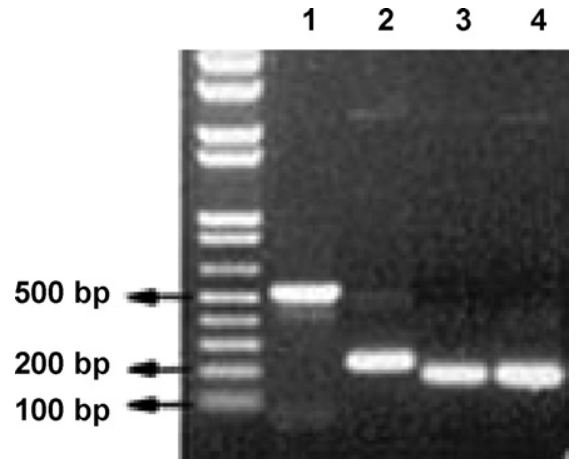

Fig. 1. Two-step PCR assembly of co-GRA1: $531 \mathrm{bp}$ full-length co-GRA1 gene (lane 1); $196 \mathrm{bp}$ and $196 \mathrm{bp}, 237 \mathrm{bp}$ intermediate gene fragment 0 (lane 2); 196 bp intermediate gene fragment 1 (lane 3); 196 bp intermediate gene fragment 3 (lane 4). DNA ladder is from Invitrogen.

onic kidney (HEK) 293 cells were transfected with the CMV/wt-GRA1 and CMV/co-GRA1 plasmids. A CMV vector containing green fluorescent protein (CMV/GFP) was used as a positive control and an empty CMV vector, as a negative control (data not shown). Expression levels of co-GRA1 and wt-GRA1 were determined by immunofluorescence and Western blotting using anti-polyhistidine antibody. The results in Fig. 2 demonstrate that the expression level of rGRA1 in HEK 293 cells is clearly higher in the HEK 293 cells transfected with the CMV/co-GRA1 compared to HEK 293 cells transfected with the CMV/wt-GRA1.

\subsection{Protein expression, purification, and characterization}

The expression of rGRA1 was induced with $1 \mathrm{mM}$ IPTG when the growing cells reached an optical density of 0.4 at $600 \mathrm{~nm}$. The cells were harvested after $16 \mathrm{~h}$, lysed, and processed. The rGRA1 protein was purified in two steps, first on a HiTrap $\mathrm{Ni}^{2+}$ Chelating HP column and then on a Superdex 200 column. The protein purity was ascertained by SDSPAGE and the results are shown in Fig. 3. The purification protocol yielded $2.5 \mathrm{mg}$ of purified rGRA1 from 11 of cell wild type GRA1 DNA vaccine (CMV/wt-GRA1)

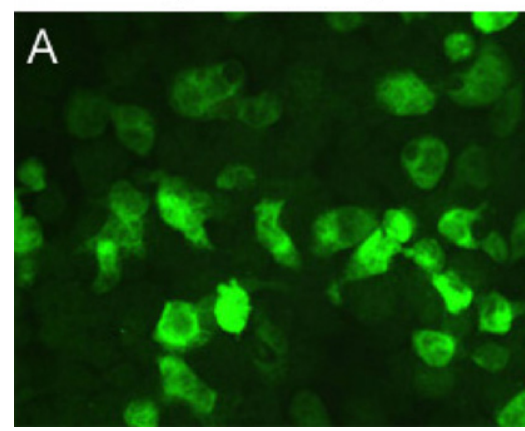

codon-optimized GRA1 DNA vaccine (CMVICo-GRA1)

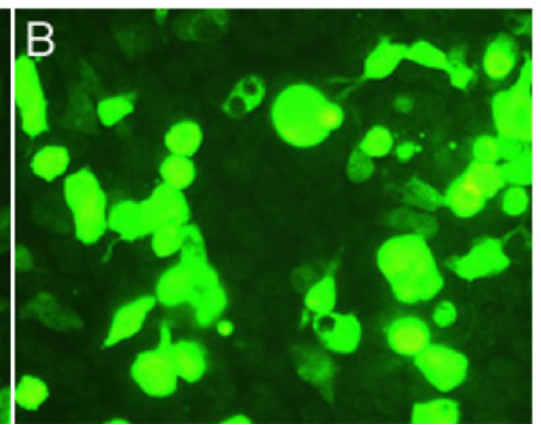

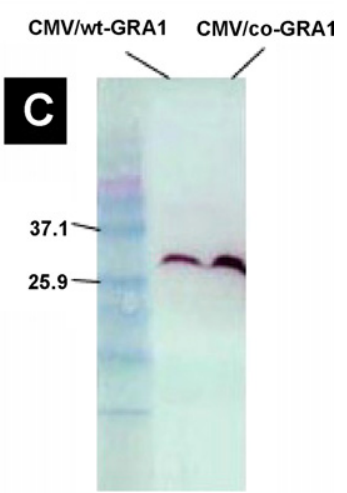

Fig. 2. In vitro transfection study results: immunofluorescence microscopy reveals that rGRA1 protein expression during in vitro expression is clearly higher with (B) CMV/co-GRA1 transfected HEK 293 cells compared to (A) CMV/wt-GRA1 transfected HEK 293 cells. (C) In the Western blot analysis of rGRA1 protein expression levels of the lysed HEK 293 cells, CMV/co-GRA1 expressed approximately $40 \%$ more protein than CMV/wt-GRA1 in HEK 293 cells as measured by ImageJ software. The protein ladder is from Invitrogen. 
Table 1

Comparison of wt-GRA1 and co-GRA1 gene sequences

\begin{tabular}{|c|c|c|c|c|c|c|c|c|c|c|c|c|c|c|c|c|c|c|c|c|}
\hline wt-GRA1 ${ }^{\mathrm{a}}$ & GCC & GAA & GGC & GGC & GAC & $\mathrm{AAC}$ & CAG & TCG & AGC & GCC & GTC & TCA & GAT & CGG & GCG & TCT & CTC & TTT & GGT & TTG \\
\hline co-GRA1 & GCT & GAG & GGA & GGA & GAC & AAC & CAG & AGC & TCT & GCT & GTG & TCC & GAT & CGC & GCC & TCT & CTG & TTC & GGC & CTG \\
\hline \multirow{2}{*}{ Diff(19) } &.. $\mathrm{T}$ &..$G$ &.. $\mathrm{~A}$ &.. $\mathrm{~A}$ & $\ldots$ & $\ldots$ & $\ldots$ & AGC & TCT &.. $\mathrm{T}$ &..$G$ &..$C$ & $\ldots$ &..$C$ &..$C$ & $\ldots$ &..$G$ &..$C$ &..$C$ & C.. \\
\hline & A & $\mathrm{E}$ & G & G & $\mathrm{D}$ & $\mathrm{N}$ & Q & S & S & A & $\mathrm{V}$ & $\mathrm{S}$ & $\mathrm{D}$ & $\mathrm{R}$ & A & $S$ & $\mathrm{~L}$ & $\mathrm{~F}$ & G & $\mathrm{L}$ \\
\hline wt-GRA1 & CTG & AGT & GGA & GGG & ACA & GGG & CAG & GGA & TTA & GGA & ATC & GGA & GAA & TCT & GTA & GAT & TTG & GAG & ATG & ATG \\
\hline co-GRA1 & CTG & TCT & GGC & GGC & ACC & GGC & CAA & GGC & CTC & GGA & ATC & GGC & GAG & TCT & GTG & GAC & CTG & GAG & ATG & ATG \\
\hline \multirow[t]{2}{*}{ Diff(15) } & $\ldots$ & TC. &..$C$ &.. $\mathrm{C}$ &.. $\mathrm{C}$ &..$C$ &.. $\mathrm{~A}$ &.. $\mathrm{C}$ & C.C & $\ldots$ & $\ldots$ &..$C$ &.. $\mathrm{G}$ & &.. $\mathrm{G}$ &..$C$ & C.. & & $\ldots$ & $\ldots$ \\
\hline & $\mathrm{L}$ & S & G & G & $\mathrm{T}$ & G & $\mathrm{Q}$ & G & $\mathrm{L}$ & G & I & G & $\mathrm{E}$ & S & $\mathrm{V}$ & $\mathrm{D}$ & $\mathrm{L}$ & $\mathrm{E}$ & M & M \\
\hline wt-GRA1 & GGG & AAC & ACG & TAT & CGT & GTG & GAG & AGA & $\mathrm{CCC}$ & $\mathrm{ACA}$ & GGC & AAC & CCG & GAC & TTG & СТC & AAG & ATC & GCC & ATT \\
\hline co-GRA1 & GGC & $\mathrm{AAC}$ & $\mathrm{ACC}$ & TAT & CGC & GTC & GAA & CGC & $\mathrm{CCC}$ & $\mathrm{ACT}$ & GGC & AAC & $\mathrm{CCC}$ & GAC & CTG & CTG & AAG & ATC & GCC & ATC \\
\hline \multirow[t]{2}{*}{$\operatorname{Diff}(13)$} & G. & $\ldots$ & .C. & $\ldots$ & G. & .T. & .AA & G. & $\ldots$ & .C. & $\ldots$ & $\ldots$ & .C. &.. $\mathrm{C}$ & $\ldots$ & .T. & $\ldots$ & $\ldots$ & $\ldots$ & .TC \\
\hline & G & $\mathrm{N}$ & $\mathrm{T}$ & $\mathrm{Y}$ & $\mathrm{R}$ & V & E & $\mathrm{R}$ & $\mathrm{P}$ & $\mathrm{T}$ & G & $\mathrm{N}$ & $\mathrm{P}$ & $\mathrm{D}$ & $\mathrm{L}$ & $\mathrm{L}$ & K & I & A & I \\
\hline wt-GRA1 & AAA & GCT & TCA & GAT & GGA & TCG & TAC & AGC & GAA & GTC & GGC & AAT & GTT & AAC & GTG & GAG & GAG & GTG & ATT & GAT \\
\hline co-GRA1 & AAG & GCC & AGC & GAC & GGC & AGC & TAC & AGC & GAG & GTG & GGC & $\mathrm{AAC}$ & GTG & AAC & GTC & GAG & GAG & GTG & ATC & GAC \\
\hline \multirow[t]{2}{*}{ Diff(17) } &.. $\mathrm{G}$ &..$C$ & AGC &..$C$ &..$C$ & AGC & $\ldots$ & $\ldots$ &.. $\mathrm{G}$ &.. $\mathrm{G}$ & $\ldots$ &..$C$ &..$G$ & $\ldots$ &..$C$ & $\ldots$ & $\ldots$ & $\ldots$ &..$C$ &.. $\mathrm{C}$ \\
\hline & $\mathrm{K}$ & A & S & $\mathrm{D}$ & G & S & $\mathrm{Y}$ & $S$ & $\mathrm{E}$ & $\mathrm{V}$ & G & $\mathrm{N}$ & $\mathrm{V}$ & $\mathrm{N}$ & V & $\mathrm{E}$ & $\mathrm{E}$ & $\mathrm{V}$ & I & $\mathrm{D}$ \\
\hline wt-GRA1 & $\mathrm{ACT}$ & ATG & AAA & AGC & ATG & CAG & AGG & GAC & GAG & GAC & ATT & TTC & CTT & CGT & GCG & TTG & $\mathrm{AAC}$ & $\mathrm{AAA}$ & GGC & GAA \\
\hline co-GRA1 & ACC & ATG & AAG & AGC & ATG & CAG & CGC & GAC & GAG & GAC & ATC & TTT & CTG & CGG & GCT & CTG & $\mathrm{AAC}$ & AAG & GGC & GAG \\
\hline \multirow[t]{2}{*}{$\operatorname{Diff}(12)$} &..$C$ & $\ldots$ &.. $\mathrm{G}$ & $\ldots$ & $\ldots$ & $\ldots$ & C.C & $\ldots$ & $\ldots$ & $\ldots$ &.. $\mathrm{C}$ &.. $\mathrm{T}$ &.. $\mathrm{G}$ &.. $\mathrm{G}$ &.. $\mathrm{T}$ & C.. & $\ldots$ &.. $\mathrm{G}$ & $\ldots$ &.. $\mathrm{G}$ \\
\hline & $\mathrm{T}$ & M & K & $S$ & M & $\mathrm{Q}$ & $\mathrm{R}$ & $\mathrm{D}$ & $\mathrm{E}$ & $\mathrm{D}$ & I & $\mathrm{F}$ & $\mathrm{L}$ & $\mathrm{R}$ & A & $\mathrm{L}$ & $\mathrm{N}$ & K & G & $\mathrm{E}$ \\
\hline wt-GRA1 & ACA & GTA & GAG & GAA & GCG & ATC & GAA & GAC & GTG & GCT & CAA & GCA & GAA & GGG & CTT & AAT & TCG & GAG & CAA & ACC \\
\hline co-GRA1 & ACC & GTG & GAG & GAA & GCC & ATC & GAG & GAC & GTC & GCC & CAG & GCC & GAG & GGG & CTC & $\mathrm{AAC}$ & AGC & GAG & CAG & ACC \\
\hline \multirow[t]{2}{*}{ Diff(15) } &..$C$ &.. $\mathrm{G}$ & $\ldots$ & $\ldots$ &..$C$ & $\ldots$ &.. $\mathrm{G}$ & $\ldots$ &..$C$ &..$C$ &.. $\mathrm{G}$ &..$C$ &.. $\mathrm{G}$ & $\ldots$ &..$C$ &..$C$ & AGC & $\ldots$ &.. $\mathrm{G}$ & $\ldots$ \\
\hline & $\mathrm{T}$ & $\mathrm{V}$ & $\mathrm{E}$ & $\mathrm{E}$ & A & I & $\mathrm{E}$ & $\mathrm{D}$ & V & A & Q & A & $\mathrm{E}$ & G & $\mathrm{L}$ & $\mathrm{N}$ & S & $\mathrm{E}$ & $\mathrm{Q}$ & $\mathrm{T}$ \\
\hline wt-GRA1 & CTG & CAA & CTG & GAA & GAT & GCA & GTG & AGC & GCG & GTG & GCG & TCT & GTT & GTT & CAA & GAC & GAG & ATG & AAG & GTG \\
\hline co-GRA1 & CTC & CAG & CTG & GAA & GAT & GCC & GTG & AGC & GCC & GTG & GCC & AGC & GTG & GTG & CAG & GAC & GAG & ATG & AAG & GTG \\
\hline \multirow[t]{2}{*}{$\operatorname{Diff}(11)$} &..$C$ &..$G$ & $\ldots$ & $\ldots$ & $\ldots$ &..$C$ & $\ldots$ & $\ldots$ &..$C$ & $\ldots$ &..$C$ & AGC &.. $\mathrm{G}$ &.. $\mathrm{G}$ &..$G$ & $\ldots$ & $\ldots$ & $\ldots$ & $\ldots$ & $\ldots$ \\
\hline & $\mathrm{L}$ & $\mathrm{Q}$ & $\mathrm{L}$ & $\mathrm{E}$ & $\mathrm{D}$ & A & $\mathrm{V}$ & $S$ & A & V & A & S & $\mathrm{V}$ & $\mathrm{V}$ & $\mathrm{Q}$ & $\mathrm{D}$ & $\mathrm{E}$ & $\mathrm{M}$ & $\mathrm{K}$ & V \\
\hline wt-GRA1 & ATC & GAC & GAT & GTG & CAG & CAG & CTT & GAA & AAG & GAC & AAA & CAA & CAG & CTT & AAG & GAT & GAC & ATT & GGG & TTC \\
\hline co-GRA1 & ATC & GAC & GAC & GTG & CAG & CAG & CTG & GAA & AAG & GAC & AAA & CAG & CAA & CTC & AAG & GAC & GAC & ATC & GGC & TTC \\
\hline \multirow[t]{2}{*}{$\operatorname{Diff}(8)$} & $\ldots$ & $\ldots$ &..$C$ & $\ldots$ & $\ldots$ & $\ldots$ &.. $\mathrm{G}$ & $\ldots$ & $\ldots$ & $\ldots$ & $\ldots$ &.. $\mathrm{G}$ &.. $\mathrm{A}$ &..$C$ & $\ldots$ &.. $\mathrm{C}$ & $\ldots$ &..$C$ &..$C$ & $\ldots$ \\
\hline & I & $\mathrm{D}$ & $\mathrm{D}$ & V & Q & $\mathrm{Q}$ & $\mathrm{L}$ & $\mathrm{E}$ & $\mathrm{K}$ & $\mathrm{D}$ & K & $\mathrm{Q}$ & $\mathrm{Q}$ & $\mathrm{L}$ & $\mathrm{K}$ & $\mathrm{D}$ & $\mathrm{D}$ & I & G & $\mathrm{F}$ \\
\hline wt-GRA1 & CTA & $\mathrm{ACA}$ & GGA & GAG & AGA & GAG & & & & & & & & & & & & & & \\
\hline co-GRA1 & CTG & $\mathrm{ACC}$ & GGC & GAG & CGC & GAG & & & & & & & & & & & & & & \\
\hline \multirow[t]{2}{*}{$\operatorname{Diff}(5)$} &..$G$ &..$C$ &..$C$ & $\ldots$ & C.C & 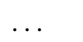 & & & & & & & & & & & & & & \\
\hline & $\mathrm{L}$ & $\mathrm{T}$ & G & $\mathrm{E}$ & $\mathrm{R}$ & E & & & & & & & & & & & & & & \\
\hline
\end{tabular}

${ }^{a}$ The first row displays the wt-GRA1 gene sequence; the second row, the CODA-optimized GRA1 gene sequence; and the third row, the modified bases in each codon. Although the codons are changed, the amino acid sequence of the GRA1 protein remains the same, as shown in the fourth row. 


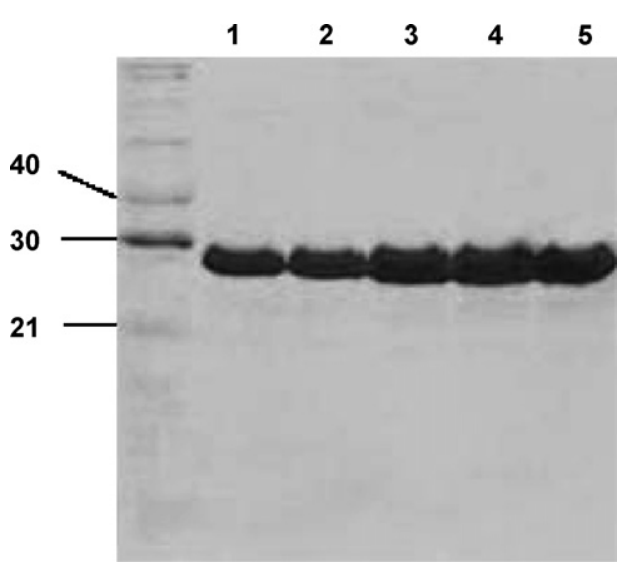

Fig. 3. SDS-PAGE analysis of purified rGRA1 loaded into each well from concentrations of 100 through $300 \mu \mathrm{g}$ (lanes 1 through 5). The protein ladder is from QuantPro (Expression Technologies, San Diego, CA).

culture. On SDS PAGE and on Western blots using by antipolyhistidine monoclonal antibody, the purified rGRA1 had an apparent molecular mass of $26 \mathrm{kD}$. The calculated molecular mass of the rGRA1, expressed from the $669 \mathrm{bp}$ ORF, was only 24,085. To resolve the discrepancy, purified rGRA1 from three separate batches were analyzed by MALDI-TOF Mass spectroscopy (MS) and each showed a peak at 24,120.

\subsection{Humoral immune response to GRAl vaccines}

The rGRA1 protein has been reported to strongly bind $T$. gondii-specific antibodies in human sera [52]. Several types of experiments were carried out to determine the humoral immune response to each type of vaccine candidate. In the first experiment, total $T$. gondii parasite lysate was probed with a pool of serum samples obtained from each group of vaccinated $B A L B / c$ mice. Each type of vaccine induced a strong antibody response against a $24 \mathrm{kD}$ protein in $T$. gondii lysate, as detected by Western blots shown in Fig. 4. No antibody response was detected in the control group, in which mice were vaccinated with Provax or an empty vector.

In the second set of experiments, serum samples from each group of vaccinated mice were tested for the presence of antiGRA1-specific IgG antibodies. The negative controls consisted of sera pools of mice vaccinated with Provax for the rGRA1-Provax group or empty vector for the DNA vaccine groups. In all vaccination groups, the amount of $\mathrm{IgG}$ antibodies significantly increased after the booster vaccination $(P<0.01)$. Fig. 5 summarizes the fluorescence intensity data collected for each group of vaccinated mice, after the prime and the boost vaccinations. Among all vaccination groups, the highest humoral immune response was achieved after boosting with rGRA1-Provax. The CMV/co-GRA1 vaccine yielded a somewhat higher antibody response than the $\mathrm{CMV} / \mathrm{wt}-\mathrm{GRA} 1-\mathrm{DNA}$ vaccine.

In the final evaluation of the humoral immune response, the frequency of the $\mathrm{IgG} 1 / \mathrm{IgG} 2$ a polarization was determined as a preliminary indication of whether one or more of the

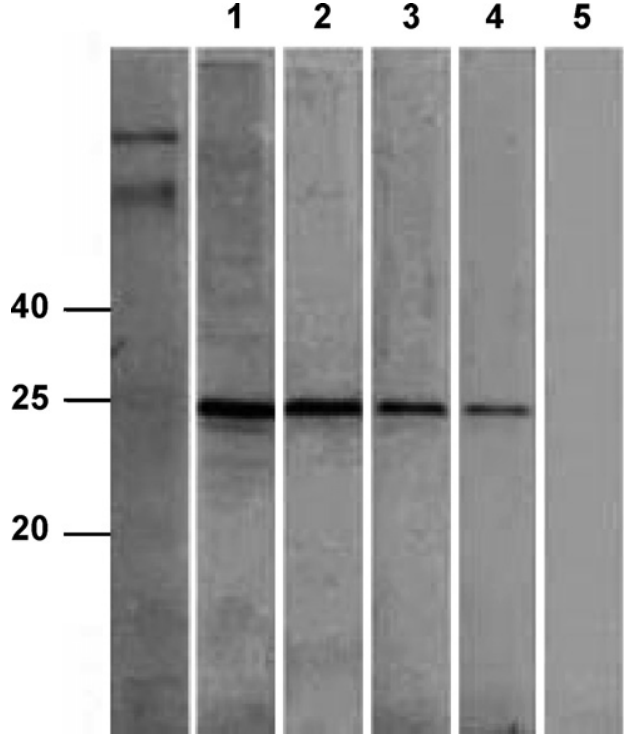

Fig. 4. Probe of native T. gondii lysate using pooled sera of mice vaccinated with rGRA1-Provax (lane 1), CMV/co-GRA1 (lane 2), CMV/wt-GRA1 (lane 3) only rGRA1 (lane 4), control groups vaccinated with Provax and empty vector (lane 5). The protein ladder is from Invitrogen.

GRA1 vaccines induced a Th1 or Th2 response. The results are shown in Fig. 6. Of eight mice vaccinated with rGRA1Provax, six showed a strong IgG1 response as well as a weaker IgG2a response; two mice experienced a nearly equivalent, but weak $\mathrm{IgG} 1$ and $\mathrm{IgG} 2$ a response (Fig. 6B). In the DNA vaccination groups, four displayed a stronger IgG2a response; three showed a stronger IgG1 response, and one had a comparable IgG1 and $\mathrm{IgG} 2 \mathrm{a}$ response (Fig. $6 \mathrm{C}$ and D). Overall, the GRA1 DNA vaccinations induced a similar pattern of Th1 and Th2 polarity, with a slight bias towards a Th1 response. Furthermore, to evaluate the contribution of the adjuvant to the observed immune responses, five mice were vaccinated with only rGRA1 protein. Similar to a previous study [31], there was a weak IgG1 and IgG2a response slightly biasing towards IgG1 response to the rGRA1 protein in the

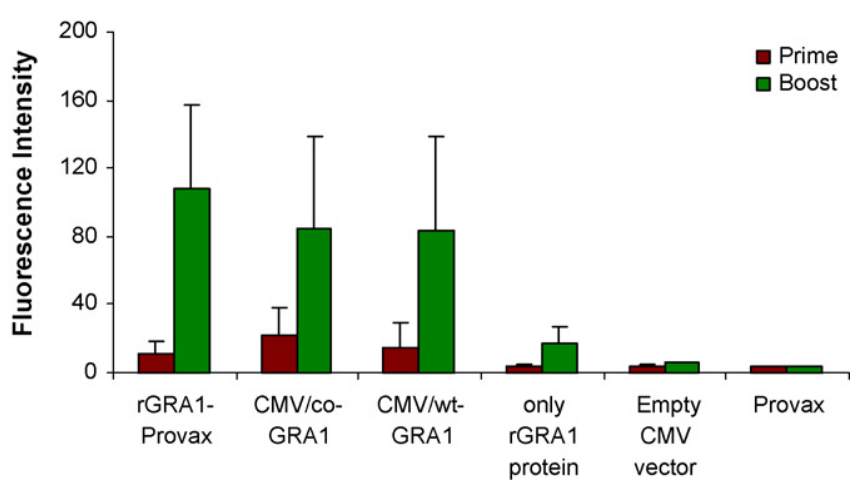

Fig. 5. IgG antibody response against GRA1 vaccines. Serum samples in each vaccine group of eight mice were collected three weeks after priming and three weeks after boosting. The brown bars represent the IgG response after the initial vaccination and the green bars represent the response after the boosting. 


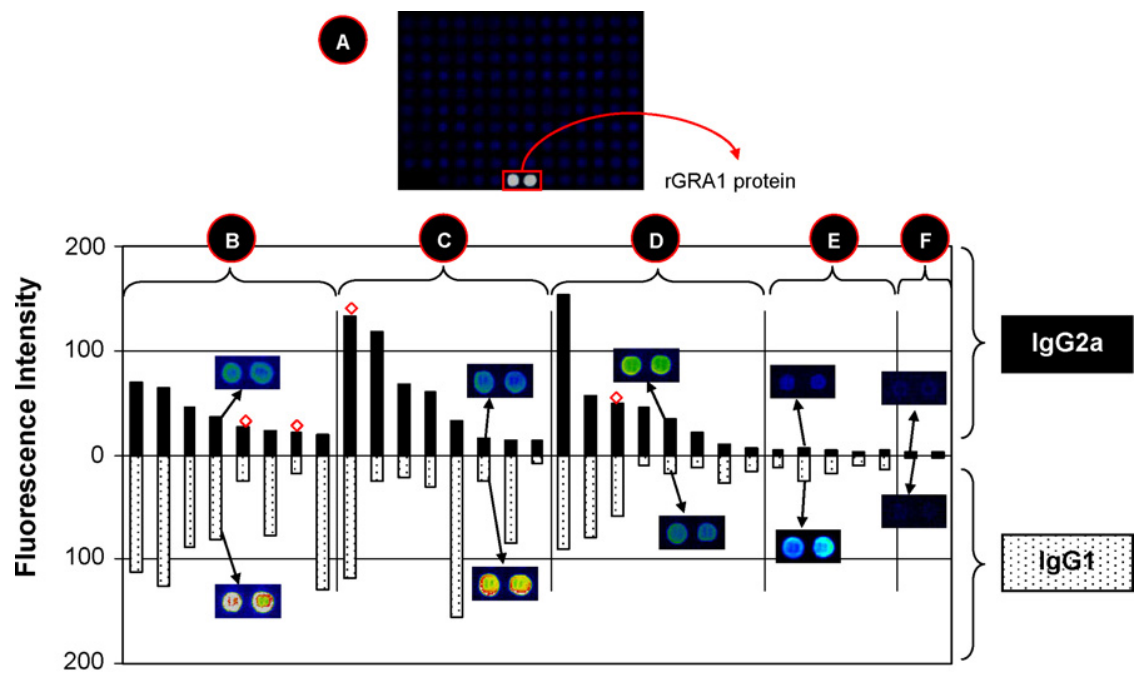

Fig. 6. GRA1 microarray analysis of IgG1 and IgG2a subclass antibodies. (A) Representative protein microarray slide compare the illuminated antibody response to rGRA1 protein printed spots. The spots were printed in duplicate with 68 different proteins from vaccinia virus and human papilloma virus as well as empty vector controls. In (B) through (F), the intensity values of serum samples collected from each mouse, vaccinated with one of the GRA1 vaccine formulations or with a control, are displayed. The solid black bars represent the IgG2a response and the dotted bars, the IgG1 response. Representative illuminated spots in duplicate are shown for each vaccination and control group. The groups have been vaccinated with the following: (B) rGRA1-Provax; (C) CMV/co-GRA1; (D) CMV/wt-GRA1; (E) only rGRA1 protein; and (F) empty vector and Provax adjuvant. The symbol ( $\diamond)$ represents the individual serum samples, which show nearly equivalent IgG1 and IgG2a responses.

absence of an adjuvant (Fig. 6E). Thus, Provax adjuvant significantly improved the protective IgG2a response to rGRA1 protein $(P=0.0029)$. All controls, containing empty vector and Provax, adjuvant, had no detectable immune response to either IgG1 or IgG2a (Fig. 6F).

\subsection{Cell-mediated immune response to rGRAl vaccines}

Splenocytes from individual immunized mice were stimulated in vitro with purified rGRA1 protein and with the mitogen, Con A, as well as with unrelated vaccinia virus $\mathrm{rH} 3 \mathrm{~L}$ protein as controls. Incorporation of $\left[{ }^{3} \mathrm{H}\right]$-thymidine was used to measure lymphocyte proliferation achieved by rGRA1 vaccines. As Table 2 reports, in the lymphoproliferation assays, the T-cell stimulation index (SI) was significantly higher with the mice vaccinated with rGRA1-Provax protein vaccine compared to the CMV/co-GRA1 vaccinated mice and $\mathrm{CMV} / \mathrm{wt}-\mathrm{GRA} 1$ vaccinated mice $(P=0.0007)$. How-

\section{Table 2}

Lymphoproliferation and cytokine production of BALB/c mice vaccinated with rGRA1-Provax, CMV/co-GRA1 and CMV/wt-GRA1

\begin{tabular}{lccc}
\hline Vaccine candidates & $\begin{array}{l}\text { Stimulation } \\
\text { index }^{\mathrm{a}}\end{array}$ & \multicolumn{2}{c}{ Cytokine production $(\mathrm{pg} / \mathrm{ml})^{\mathrm{b}}$} \\
\cline { 3 - 4 } & & IFN- $\gamma$ & $\mathrm{IL}-4$ \\
\hline rGRA1-Provax & $4.7 \pm 0.2$ & $1502 \pm 301$ & $28 \pm 0$ \\
CMV/co-GRA1 & $3.4 \pm 0.6$ & $565 \pm 22$ & $16 \pm 4$ \\
CMV/wt-GRA1 & $2.8 \pm 0.4$ & $481 \pm 25$ & $15 \pm 2$ \\
\hline
\end{tabular}

${ }^{\text {a }}$ As described in methods, the stimulation index is the ratio of the mean counts per minute (cpm) of spleen cells stimulated with varying concentrations of rGRA1 to the mean cpm of controls.

$\mathrm{b}$ The culture supernatants were assayed for cytokine production. Values for IFN- $\gamma$ and IL-4 were obtained from $72 \mathrm{~h}$ culture. ever, there was no statistical difference in lymphoproliferative response in mice vaccinated with either the CMV/wt-GRA1 or the CMV/co-GRA1 DNA vaccines $(P=0.1)$. In the controls, the mean cpm, $2607 \pm 349$, of the non-stimulated cells from GRA1-vaccinated groups was similar to the mean cpm of $2586 \pm 406$ from naïve mice spleen cells stimulated with rGRA1 and to the mean cpm of $2866 \pm 403$ GRA1-vaccinated mice spleen cells stimulated with unrelated vaccinia virus $\mathrm{rH} 3 \mathrm{~L}$ protein. Mice vaccinated with only rGRA1 protein showed a slightly higher SI compared to control mice (data not shown). For all groups, stimulation with Con A displayed counts above 50,000 cpm. In addition, spleen cells from all experimental and control groups proliferated to comparable levels in response to Con $\mathrm{A}$ and showed no response to vaccinia virus $\mathrm{rH} 3 \mathrm{~L}$ protein.

As a measure of the Th1 or Th2 immune response, the production of IFN- $\gamma$ and IL-4 in spleen cells of vaccinated mice and control groups were determined by ELISA (Table 2). After stimulating with rGRA1, the production of IFN- $\gamma$ at $72 \mathrm{~h}$ was significantly higher in mice vaccinated with the rGRA1-Provax vaccine compared to mice vaccinated with either DNA vaccine $(P=0.0083)$. The IFN- $\gamma$ levels were only slightly higher in the mice vaccinated with $\mathrm{CMV} / \mathrm{co}-$ GRA1, compared to mice vaccinated with CMV/wt-GRA1 $(P=0.5)$. The IFN- $\gamma$ levels in mice vaccinated with Provax adjuvant was $89 \pm 12 \mathrm{pg} / \mathrm{ml}$ and were below the cut-off value. The splenocytes from mice vaccinated with empty vector showed nonspecific IFN- $\gamma$ production at low levels of $243 \pm 48 \mathrm{pg} / \mathrm{ml}$. IL-4 levels were assayed in cell culture supernatants at two time points after stimulation with rGRA1. IL-4 levels were not detected in any animal group at $24 \mathrm{~h}$ (data not shown). In contrast, a significant increase in IL- 


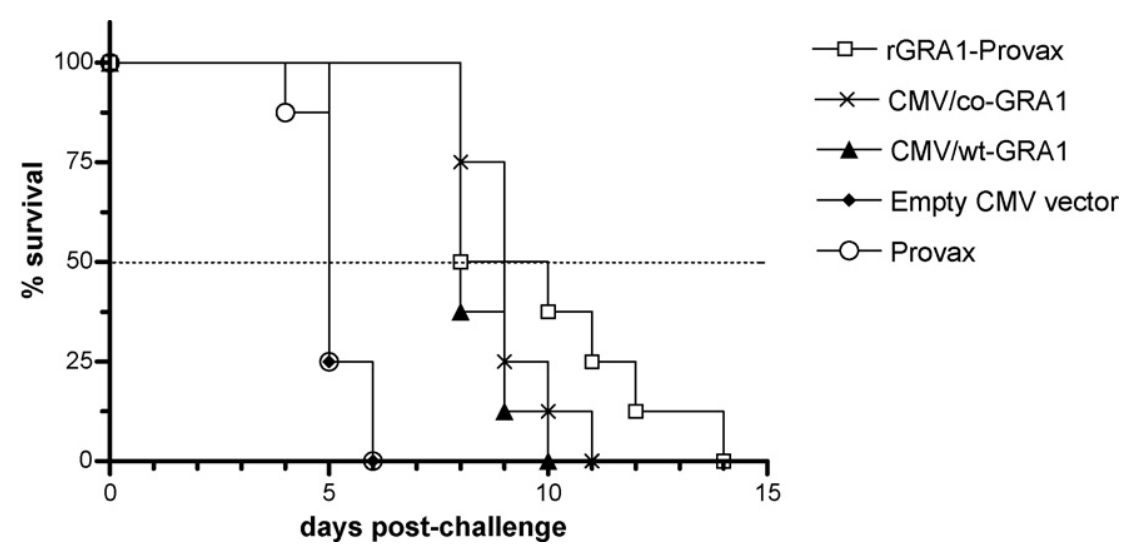

Fig. 7. Survival profiles of vaccinated BALB/c mice against lethal toxoplasmosis. All mice were challenged with $1 \times 10^{5}$ T. gondii RH strain tachyzoites nine weeks after the prime vaccination. T. gondii tachyzoites were administered to mice vaccinated with rGRA1-Provax ( $\mathbf{\square})$, CMV/co-GRA1 ( $\times$ ), CMV/wt-GRA1 $(\boldsymbol{\Lambda})$, and the control groups, empty vector $(\checkmark)$ or Provax $(\bigcirc)$.

4 was detected after $72 \mathrm{~h}$ of stimulation in mice vaccinated with rGRA1-Provax compared to naïve animals or the control groups vaccinated only with Provax $(P<0.0001)$. The IL-4 levels produced by mice vaccinated with either DNA vaccine were only slightly higher than mice vaccinated with naïve mice or empty vector. IL-4 production in control groups of mice vaccinated with empty vector and Provax adjuvant was $12 \pm 2$ and $13 \pm 2 \mathrm{pg} / \mathrm{ml}$, respectively. Mice vaccinated with only rGRA1 protein achieved cytokine levels slightly above cut-off value (data not shown). IL-4 and IFN- $\gamma$ levels produced by spleen cells obtained from GRA1 vaccinations after stimulation with unrelated vaccinia virus $\mathrm{rH} 3 \mathrm{~L}$ protein was below the cut-off value (data not shown). Taken together, all vaccines induced higher IFN- $\gamma$ levels compared to IL-4 levels, with the rGRA1-Provax vaccine producing the highest IFN- $\gamma$ levels among all groups.

\subsection{Protection against lethal toxoplasmosis}

Protection against lethal toxoplasmosis was compared in vaccinated BALB/c mice using T. gondii RH strain. Animals were intraperitoneally injected with $1 \times 10^{5} \mathrm{RH}$ strain tachyzoites nine weeks after the prime vaccination. After challenging in the control groups, mice vaccinated with only Provax or empty CMV vector survived $5.1 \pm 0.6$ and $5.3 \pm 0.5$ days, respectively. Survival prolonged significantly in groups vaccinated with rGRA1-Provax, CMV/co-GRA1, and CMV/wt-GRA1 compared to controls $(P<0.0001)$. Mice vaccinated with rGRA1-Provax survived approximately $9.8 \pm 2.3$ days, which was slightly higher than the mice vaccinated with CMV/wt-GRA1 ( $8.5 \pm 0.8$ days) and CMV/co-GRA1 $(9.1 \pm 1$ days $)(P=0.2)$. Nine days after challenging, $50 \%$ of mice vaccinated with rGRA1-Provax were alive compared to $25 \%$ of CMV/co-GRA1 and $12.5 \%$ CMV/wt-GRA1 vaccinated mice. Eleven days after challenging, among three vaccination groups, $25 \%$ of mice vaccinated with rGRA1-Provax were alive and none of the CMV/co-GRA1 and CMV/wt-GRA1 DNA vaccinated mice was alive. Survival prolonged approximately 1.6 times in $\mathrm{CMV} / \mathrm{wt}-\mathrm{GRA} 1$ vaccinated group, 1.7 times in $\mathrm{CMV} / \mathrm{co}-$ GRA1 vaccinated group and 1.9 times in rGRA1-Provax vaccinated group compared to controls. Overall, the rGRA1Provax vaccination prolonged survival in $12.5 \%$ of mice up to 14 days, almost doubled the survival time compared to controls and thus, afforded the most protection among all vaccination groups. The results are summarized in Fig. 7.

\section{Discussion}

Although vaccine research against toxoplasmosis shows promise, much effort is yet required to develop a safe and effective $T$. gondii vaccine with long-lasting effects. To date, the only commercial vaccine, which has been developed using live tachyzoites from the S48 T. gondii strain, is used for protection against toxoplasmosis in sheep [53]. The vaccine is not widely used as a consequence of reactivation of the live tachyzoites to the pathogenic form, short shelf life, and high cost [6]. To circumvent the negative features, current research is focused on developing safe vaccines from DNA segments or from antigenic protein(s) of $T$. gondii.

GRA1 is considered to be a promising vaccine candidate because GRA1 DNA vaccines elicit immune responses as well as afford protection in rodent and livestock models [8,26-28]. Purified rGRA1 protein vaccines have also found to be immunogenic, however protection studies in animal models haven't been conducted yet $[8,27,31]$. Thus, the present study focuses on the immunogenicity and protection potency of three types of GRA1-derived vaccines candidates. The GRA1 vaccines in this study include a wild type GRA1 DNA vaccine (CMV/wt-GRA1), a GRA1 DNA vaccine that has been codon optimized for expression in mammalian cells (CMV/co-GRA1), and a GRA1 recombinant protein vaccine adjuvanted with Provax (rGRA1-Provax).

DNA vaccination strategy has become popular in 1990s. Intramuscular injection of DNA vaccines mostly induce dom- 
inant Th1 type immune response as shown by the induction of IgG2a antibody response, increased levels of IFN- $\gamma$ and small quantities of IL-4 production [54]. One of the limiting factors in inducing strong immune response after the administration of wild type DNA vaccines is the low (picogram to nanogram) quantities of protein expression in vivo [54]. Another factor for suboptimal protein expression occurs when the codon usage of the target gene in a DNA vaccine is different from the mammalian cells. The presence of rare codons in cloned genes affects mRNA and plasmid stability as well as protein expression level. The excessive presence of rare codons can result in ribosome stalling, slow translation, and translation errors. In some cases, rare codons inhibit protein synthesis and cell growth [55]. Several approaches have been used successfully to compound these problems. One of them is to use cytomegalovirus (CMV) promoter in DNA vaccines to increase gene expression in host cells [54]. The other common strategy is to remove rare codons by codon optimization to increase the protein expression. For this purpose, in the present study, a CMV promoter containing plasmid and codon optimization strategies were used to increase the efficacy of wild type GRA1 DNA vaccination. To optimize the codon usage of wild type GRA1 for expression in mammalian systems, the novel algorithm for codon optimization, termed CODA was used. CODA includes codon substitutions to facilitate the error-free self-assembly of the gene from DNA oligonucleotides in a few simple steps [56]. In the present study, after the assembly of co-GRA1 and construction of CMV/co-GRA1 plasmid, a comparison of CMV/co-GRA1 and CMV/wt-GRA1 protein expression levels in HEK 293 cells demonstrated that CMV/co-GRA1 expressed rGRA1 protein clearly higher than CMV/wt-GRA1.

Immune protection against $T$. gondii in mice is primarily correlated with IFN- $\gamma$ level [3-5]. IgG2a production from B cells is under the influence of Th1 response or low IFN- $\gamma$ secretion [4] thus, a vaccine candidate against toxoplasmosis has to primarily increase IgG2a and especially IFN- $\gamma$ levels. In the present study, both types of DNA vaccines elicited a significant humoral and cellular immune response as well as increased survival rates in mice infected with the lethal RH tachyzoites compared to controls. After prime and boost vaccinations, CMV/co-GRA1 vaccine yielded a higher $\mathrm{IgG}$ antibody response than the CMV/wt-GRA1 vaccine. During the evaluation of subgroup IgG antibody response, $50 \%$ of both DNA vaccines have polarized towards Th1 response. In the previous GRA1 DNA vaccination studies, the VR1020 plasmid encoding GRA1 achieved similar results $[26,28]$; however, the same plasmid mostly produced an $\operatorname{IgG} 1 / \mathrm{Th} 2$ response [8]. During the evaluation of antigen specific lymphocyte proliferation and IFN- $\gamma$ production of spleen cells, stimulated with endotoxin depleted rGRA1 protein, CMV/wt-GRA1 and CMV/co-GRA1 DNA vaccinations showed significant increase compared to controls which were similar in the previous studies using the $T$. gondii lysate antigens for the stimulation of spleen cells $[26,28]$. In addition, an increase in IL-4 levels was obtained from the spleen cells stimulated $72 \mathrm{~h}$ compared to controls. An increase in IL-4 levels, which was not detected in previous studies, explains the correlation between the IgG1 response and IL-4 response obtained from DNA vaccinations. The reason of the $\mathrm{IgG} 1 / \mathrm{Th} 2$ and $\mathrm{IgG} 2 \mathrm{a} / \mathrm{Th} 1$ response variation between vaccinated animals observed in the present study and previous DNA vaccination studies is not yet known; however, the site of antigenic protein expression (i.e., myocytes versus dendritic cells/skin cells), differential stimulation of innate immune system, or the immune system of animal used in the experiments may be responsible for this variation [54].

During the evaluation of protection potency, CMV/coGRA1 vaccine was slightly better than CMV/wt-GRA1 vaccine, which was comparable to immune responses elicited by the vaccines. Nine days after challenging $25 \%$ of $\mathrm{CMV} / \mathrm{co}-$ GRA1 and $12.5 \% \mathrm{CMV} / \mathrm{wt}$-GRA1 vaccinated mice were alive and survival was prolonged in BALB/c mice 1.6 and 1.7 times, respectively compared to controls that survived approximately five days after challenging. In two consecutive studies, VR1020 plasmid encoding rGRA1 protein was evaluated in $\mathrm{C} 3 \mathrm{H}, \mathrm{BALB} / \mathrm{c}$ and C57BL/6 mice with nonstandardized doses of $T$. gondii IPB-G and $76 \mathrm{~K}$ strain cysts $[26,28]$. In the BALB/c mice group, protection after challenging with 200 and 50 cysts of T. gondii IPB-G strain was $0 \%$ and $70 \%$ whereas protection in controls mice was $0 \%$ and $80 \%$, respectively. In the $\mathrm{C} 3 \mathrm{H}$ mice group protection after challenging with 50 cysts of IPB-G strain and 50 cysts of $76 \mathrm{~K}$ strain was $70 \%$ and $90 \%$ whereas protection in the control groups were $10 \%$ and $50 \%$, respectively [28]. In the following study, two groups of four $\mathrm{C} 3 \mathrm{H}$ mice were challenged with 40 cysts of IPB-G strain and protection was $75 \%$ and $100 \%$ in the vaccinated groups and $0 \%$ and $25 \%$ in the control groups, respectively [26].

In the literature, similar to the present study, protection was determined using lethal doses of RH strain tachyzoites and among these, the best survival was conferred by SAG1 encoding plasmid in $\mathrm{C} 3 \mathrm{H}$ and $\mathrm{BALB} / \mathrm{c}$ mice groups in which the protection was $100 \%$ and $80 \%$ compared to $30 \%$ and $20 \%$ protection in control groups, respectively [23]. Other studies using ROP2 or SAG1 single gene DNA vaccinations did not increase survival significantly $[12,18]$; however, ROP2SAG1 cocktail vaccine and DNA vaccine encoding $T$. gondii genomic library increased survival up to four times compared to controls $[12,13]$. Overall, the elicited immune response, as determined by IgG1, IgG2a, IFN- $\gamma$ and IL-4 levels, as well as the protection potency was somewhat higher for the CMV/co-GRA1 DNA vaccine than for the CMV/wt-GRA1 DNA vaccine and mammalian codon-optimized GRA1 DNA vaccine showed immunogenicity and protection comparable to previous vaccination studies. However, immunogenicity and protection potency of codon-optimized GRA1 DNA vaccine did not increase, similar to the results obtained from in vitro studies. The reason might be that the $40 \%$ increase achieved by codon-optimized GRA1 DNA vaccine in vitro may not be enough to significantly increase the immune response and protection because the low (only picogram to 
nanogram) quantities of protein expression in vivo is the most important limiting factor of DNA vaccines in inducing strong immune response [54]. As a result, codon-optimization of GRA1 marginally improved the properties of the GRA1 DNA vaccine.

The rGRA1 protein vaccine was prepared from recombinant GRA1 purified to homogeneity, resulting in an overall yield of $2.5 \mathrm{mg}$ rGRA1 protein per liter of cultured $E$. coli cells. Although rGRA1 protein has a calculated molecular mass of 24,085 , the recombinant protein migrates as a $26 \mathrm{kD}$ protein on SDS-PAGE, an anomaly also observed in other laboratories. To resolve the discrepancy, the molecular mass of rGRA1 protein was determined by MALDI-TOF mass spectroscopy to be 24,120 . GRA1 is located in the electrondense secretory organelles, which continuously release their content into the parasitophorous vacuole (PV) during the intracellular development of $T$. gondii. GRA1 functions as a calcium-binding protein and is found in a soluble form in the lumen and network of the PV during invasion of the host cell $[57,58]$. Calmodulin protein is an EF-hand $\mathrm{Ca}^{2+}$ binding protein $[59,60]$. Calmodulin protein demonstrates altered migration on SDS PAGE gels upon $\mathrm{Ca}^{2+}$ binding [61-63]. Recombinant and naïve GRA1 protein has two EF-hand $\mathrm{Ca}^{2+}$ binding sites also [57,58]. Thus, the $\mathrm{Ca}^{2+}$ binding property of rGRA1 protein might be causing the discrepancy similar to the one detected in calmodulin protein.

The immunogenicity of rGRA1 protein was evaluated in previous studies, however protection potency and cellular immune response of an adjuvanted rGRA1 protein vaccine was not evaluated comprehensively $[8,27,31]$. To formulate the protein vaccine for the present research, purified and endotoxin depleted rGRA1 protein was adjuvanted to Provax, which is known to be a strong inducer of Th1 cytokine and antigen-specific CD8 lymphocyte production. Indeed, Provax is prepared by mixing previously known strong adjuvants squalane and pluronic L121 to Tween-80 [32,33,64]. Adjuvants have been reported to increase the immunogenicity of protein vaccines [64]. A similar observation was made in the experiments reported herein. Importantly, the Provax adjuvant significantly enhanced the humoral and cellular immune response to the rGRA1 protein vaccine. As shown in results, the highest IgG antibody response was achieved after boosting with rGRA1-Provax among all GRA1-derived vaccinations. rGRA1-Provax induced a strong IgG1 response and a weaker, but still prominent, IgG2a response. The rGRA1-Provax vaccination increased IFN- $\gamma$ production approximately three times more than the GRA1 DNA vaccines. Consistent with IgG1 response, small quantities of IL-4 levels were detected after $72 \mathrm{~h}$ stimulation of spleen cells with endotoxin depleted rGRA1 protein. Overall, the Provax adjuvant significantly enhanced the protective IgG2a and IFN- $\gamma$ response to the rGRA1 protein. Consistent with the strong immune response, the rGRA1-Provax vaccine nearly doubled the survival rate in mice against lethal $T$. gondii infection. Vaccination studies using purified recombinant proteins of $T$. gondii are few compared to DNA vaccinations. Recombinant SAG1 protein adjuvanted with alum increased survival $44 \%$ compared to $20 \%$ in the control group after challenge with lethal doses of RH strain tachyzoites [24] and contrarily, in another vaccination trial, the mortality in mice after vaccination with adjuvanted SAG1 protein was significantly higher than the controls [30].

Thus, the present study comprehensively evaluates immunogenicity and protection potency of an rGRA1 protein vaccine for the first time and compares the results with that of the two GRA1 DNA vaccines. Overall, the rGRA1Provax vaccine appears to be somewhat better in all measured immune responses, particularly the IFN- $\gamma$ level which is primarily correlated with immune protection against $T$. gondii in mice $[3,4]$. As a result of this strong immune response, the protection potency of the rGRA1-Provax vaccine in the BALB/c mice against the RH strain $T$. gondii infection was also better than the two GRA1 DNA vaccines. The reason for the increased immunogenicity and protection of the recombinant GRA1 protein vaccine is not yet clear and requires additional experiments to determine whether the outcome would be different by varying the protein concentration or the type of the adjuvant. Consequently, commercially available successful recombinant protein vaccines against Hepatitis B Virus and Human papillomavirus and the immunogenicity of the adjuvanted rGRA1 protein vaccine shown in the present study, address the importance of developing recombinant protein vaccine strategies against toxoplasmosis.

\section{Acknowledgements}

The research was partially supported by a NATO Science Fellowship (NATO-A2) given by the Scientific and Technical Research Council of Turkey (TUBITAK) to M.D. and by a U.S. National Science Foundation (Grant IIS-0326037 to R.H.L and G.W.H.). The authors are pleased to acknowledge Dr. Naomi Morrissette at University of California, Irvine for her gift of T. gondii RH strain tachyzoites. M.D. also acknowledges the help of Republic of Turkey Ministry of Health and Dr. Cihanser Erel.

\section{References}

[1] Montoya JG, Liesenfeld O. Toxoplasmosis. Lancet 2004;363:1965-76.

[2] National Institute of Allergy and Infectious Diseases Biodefense Research Agenda for Category B and C Priority Pathogens, June 2003 [Online]. http://www3.niaid.nih.gov/Biodefense/Research/ categorybandc.pdf. Assessed 1 April 2006.

[3] Denkers EY. From cells to signaling cascades: manipulation of innate immunity by Toxoplasma gondii. FEMS Immunol Med Microbiol 2003;39:193-203.

[4] Pier GB. Vaccines and vaccination. In: Pier GB, Lyczak JB, Wetzler LM, editors. Immunology, infection, and immunity. Washington, D.C: American Society for Microbiology; 2004. p. 497-528.

[5] Denkers EY, Gazzinelli RT. Regulation and function of T-cell-mediated immunity during Toxoplasma gondii infection. Clin Microbiol Rev 1998;11:569-88. 
[6] Bhopale GM. Development of a vaccine for toxoplasmosis: current status. Mic Infect 2003;5:457-62.

[7] Angus CW, Klivington-Evans D, Dubey JP, Kovacs JA. Immunization with a DNA plasmid encoding the SAG1 (P30) protein of Toxoplasma gondii is immunogenic and protective in rodents. J Infect Dis 2000;181:317-24.

[8] Bivas-Benita M, Laloup M, Versteyhe S, Dewit J, De Braekeleer J, Jongert E, et al. Generation of Toxoplasma gondii GRA1 protein and DNA vaccine loaded chitosan particles: preparation, characterization, and preliminary in vivo studies. Int J Pharm 2003;266:17-27.

[9] Bonenfant C, Dimier-Poisson I, Velge-Roussel F, Buzoni-Gatel D, Del Giudice G, Rappuoli R, et al. Intranasal immunization with SAG1 nontoxic mutant heat labile enterotoxins protects mice against Toxoplasma gondii. Infect Immun 2001;69:1605-12.

[10] Couper KN, Nielsen HV, Petersen E, Roberts F, Roberts CW, Alexander J. DNA vaccination with the immunodominant tachyzoite surface antigen (SAG-1) protects against adult acquired Toxoplasma gondii infection but does not prevent maternofoetal transmission. Vaccine 2003;21:2813-20.

[11] Desolme B, Mevelec MN, Buzoni-Gatel D, Bout D. Induction of protective immunity against toxoplasmosis in mice by DNA immunization with a plasmid encoding Toxoplasma gondii GRA4 gene. Vaccine 2000;18:2512-21.

[12] Fachado A, Rodriguez A, Angel SO. Protective effect of a naked DNA vaccine cocktail against lethal toxoplasmosis in mice. Vaccine 2003;21:1327-35.

[13] Fachado A, Rodriguez A, Molina J, Silverio JC, Marino AP, Pinto LM, et al. Long-term protective immune response elicited by vaccination with an expression genomic library of Toxoplasma gondii. Infect Immun 2003;71:5407-11.

[14] Haumont ML, Delhaye L, Garcia M, Jurado P, Mazza V, Daminet $\mathrm{V}$, et al. Protective immunity against congenital toxoplasmosis with recombinant SAG1 protein in a Guinea pig model. Infect Immun 2000;68:4948-53

[15] Ismael AB, Sekkai D, Collin C, Bout D, Mevelec MN. The MIC3 gene of Toxoplasma gondii is a novel potent vaccine candidate against toxoplasmosis. Infect Immun 2003;71:6222-8.

[16] Letscher-Bru V, Villard O, Risse B, Zauke M, Klein JP, Kien TT. Protective effect of vaccination with a combination of recombinant surface antigen 1 and interleukin 12 against toxoplasmosis in mice. Infect Immun 1998;66:4503-6.

[17] Letscher-Bru V, Pfaff AW, Abou-Bacar A, Filisetti D, Antoni E, Villard $\mathrm{O}$, et al. Vaccination with Toxoplasma gondii SAG-1 protein is protective against congenital toxoplasmosis in $\mathrm{BALB} / \mathrm{c}$ mice but not in CBA/J mice. Infect Immun 2003;71:6615-9.

[18] Leyva R, Herion P, Saavedra R. Genetic immunization with plasmid DNA coding for the ROP2 protein of Toxoplasma gondii. Parasitol Res 2001;87:70-9.

[19] Martin V, Supanitsky A, Echeverria PC, Litwin S, Tanos T, De Roodt AR, et al. Recombinant GRA4 or ROP2 protein combined with alum or the GRA4 gene provides partial protection in chronic murine models of toxoplasmosis. Clin Diagn Lab Immunol 2004;11:704-10.

[20] Mevelec MN, Bout D, Desolme B, Marchand H, Magne R, Bruneel $\mathrm{O}$, et al. Evaluation of protective effect of DNA vaccination with genes encoding antigens GRA4 and SAG1 associated with GM-CSF plasmid, against acute, chronical and congenital toxoplasmosis in mice. Vaccine 2005;23:4489-99.

[21] Mishima M, Xuan X, Shioda A, Omata Y, Fujisaki K, Nagasawa H, et al. Modified protection against Toxoplasma gondii lethal infection and brain cyst formation by vaccination with SAG2 and SRS1. J Vet Med Sci 2001;63:433-8.

[22] Mohamed RM, Aosai F, Chen M, Mun HS, Norose K, Belal US, et al. Induction of protective immunity by DNA vaccination with Toxoplasma gondii HSP70, HSP30 and SAG1 genes. Vaccine 2003;21: 2852-61.

[23] Nielsen HV, Lauemoller SL, Christiansen L, Buus S, Fomsgaard A, Petersen E. Complete protection against lethal Toxoplasma gondii infection in mice immunized with a plasmid encoding the SAG1 gene. Infect Immun 1999;67:6358-63.

[24] Petersen E, Henrik VN, Christiansen L, Spenter J. Immunization with $E$. coli produced recombinant $T$. gondii SAG1 with alum as adjuvant protect mice against lethal infection with Toxoplasma gondii. Vaccine 1998;16:1283-9.

[25] Roque-Resendiz JL, Rosales R, Herion P. MVA ROP2 vaccinia virus recombinant as a vaccine candidate for toxoplasmosis. Parasitology 2004;128:397-405.

[26] Scorza T, D'Souza S, Laloup M, Dewit J, De Braekeleer J, Verschueren $\mathrm{H}$, et al. A GRA1 DNA vaccine primes cytolytic CD8_T cells to control acute Toxoplasma gondii infection. Infect Immun 2003;71:309-16.

[27] Supply P, Sutton P, Coughlan SN, Bilo K, Saman E, Trees AJ, et al. Immunogenicity of recombinant BCG producing the GRA1 antigen from Toxoplasma gondii. Vaccine 1999;17:705-14.

[28] Vercammen M, Scorza T, Huygen K, De Braekeleer J, Diet R, Jacobs $\mathrm{D}$, et al. DNA vaccination with genes encoding Toxoplasma gondii antigens GRA1, GRA7 and ROP2 induces partially protective immunity against lethal challenge in mice. Infect Immun 2000;68:38-45.

[29] Yang CD, Chang GN, Chao D. Protective immunity against Toxoplasma gondii in mice induced by a chimeric protein $\mathrm{rSAG} 1 / 2$. Parasitol Res 2004;92:58-64.

[30] Kasper LH, Currie KM, Bradley MS. An unexpected response to vaccination with a purified major membrane tachyzoite antigen (P30) of Toxoplasma gondii. J Immunol 1985;134:3426-31.

[31] Kato M, Claveria FG, Maki Y, Tanaka T, Suzuki N, Nagasawa H. Toxoplasma gondii antigens GRA1 (p24) and SAG1 (p30): a comparison of their stimulatory influence on T-cell activation and cytokine expression in in vitro cultures. Pathobiology 2005;72:160-4.

[32] Rajananthanan P, Attard GS, Sheikh NA, Morrow WJ. Novel aggregate structure adjuvants modulate lymphocyte proliferation and Th1 and Th2 cytokine profiles in ovalbumin immunized mice. Vaccine 1999;18:140-52.

[33] Sheikh NA, Attard GS, van Rooijen N, Rajananthanan P, Hariharan $\mathrm{K}$, Yang YW, et al. Differential requirements for CTL generation by novel immunostimulants: APC tropism, use of the TAP-independent processing pathway, and dependency on CD80/CD86 costimulation. Vaccine 2003;21:3775-88

[34] Andre S, Seed B, Eberle J, Schraut W, Bultmann A, Haas J. Increased immune response elicited by DNA vaccination with a synthetic gp120 sequence with optimized codon usage. J Virol 1998;72: 1497-503.

[35] Casimiro DR, Tang A, Perry HC, Long RS, Chen M, Heidecker GJ, et al. Vaccine-induced immune responses in rodents and nonhuman primates by use of a humanized human immunodeficiency virus type 1 pol gene. J Virol 2002;76:185-94.

[36] Deml L, Bojak A, Steck S, Graf M, Wild J, Schirmbeck R, et al. Multiple effects of codon usage optimization on expression and immunogenicity of DNA candidate vaccines encoding the human immunodeficiency virus type $1 \mathrm{Gag}$ protein. J Virol 2001;75:10991-1001.

[37] Disbrow GL, Sunitha I, Baker CC, Hanover J, Schlegel R. Codon optimization of the HPV-16 E5 gene enhances protein expression. Virology 2003;311:105-14.

[38] Hamdan FF, Mousa A, Ribeiro P. Codon optimization improves heterologous expression of a Schistosoma mansoni cDNA in HEK293 cells. Parasitol Res 2002;88:583-6.

[39] Mossadegh N, Gissmann L, Muller M, Zentgraf H, Alonso A, Tomakidi P. Codon optimization of the human papillomavirus 11 (HPV 11) L1 gene leads to increased gene expression and formation of virus-like particles in mammalian epithelial cells. Virology 2004;326:57-66.

[40] Nagata T, Uchijima M, Yoshida A, Kawashima M, Koide Y. Codon optimization effect on translational efficiency of DNA vaccine in mammalian cells: analysis of plasmid DNA encoding a CTL epitope derived from microorganisms. Biochem Biophys Res Commun 1999;261:445-51.

[41] Narum DL, Kumar S, Rogers WO, Fuhrmann SR, Liang H, Oakley M, et al. Codon optimization of gene fragments encoding Plasmodium fal- 
ciparum merzoite proteins enhances DNA vaccine protein expression and immunogenicity in mice. Infect Immun 2001;69:7250-3.

[42] Ramakrishna L, Anand KK, Mohankumar KM, Ranga U. Codon optimization of the tat antigen of human immunodeficiency virus type 1 generates strong immune responses in mice following genetic immunization. J Virol 2004;78:9174-89.

[43] Stratford R, Douce G, Zhang-Barber L, Fairweather N, Eskola J, Dougan $\mathrm{G}$. Influence of codon usage on the immunogenicity of a DNA vaccine against tetanus. Vaccine 2000;19:810-5.

[44] Strugnell RA, Drew D, Mercieca J, DiNatale S, Firez N, Dunstan $\mathrm{SJ}$, et al. DNA vaccines for bacterial infections. Immunol Cell Biol 1997;75:364-9.

[45] Uchijima M, Yoshida A, Nagata T, Koide Y. Optimization of codon usage of plasmid DNA vaccine is required for the effective MHC class Irestricted $\mathrm{T}$ cell responses against an intracellular bacterium. J Immunol 1998;161:5594-9.

[46] Vinner L, Nielsen HV, Bryder K, Corbet S, Nielsen C, Fomsgaard A. Gene gun DNA vaccination with Rev-independent synthetic HIV-1 gp160 envelope gene using mammalian codons. Vaccine 1999;17:2166-75.

[47] zur Megede J, Chen MC, Doe B, Schaefer M, Greer CE, Selby $\mathrm{M}$, et al. Increased expression and immunogenicity of sequencemodified human immunodeficiency virus type 1 gag gene. J Virol 2000;74:2628-35.

[48] Davies DH, Liang X, Hernandez JE, Randall A, Hirst S, Mu Y, et al. Profiling the humoral immune response to infection by using proteome microarrays: high-throughput vaccine and diagnostic antigen discovery. Proc Natl Acad Sci USA 2005;102:547-52.

[49] Hiszczyńska-Sawicka E, Brillowska-Dabrowska A, Dabrowski S, Pietkiewicz H, Myjak P, Kur J. High yield expression and single-step purification of Toxoplasma gondii SAG1, GRA1, and GRA7 antigens in Escherichia coli. Protein Expr Purif 2003;27:150-7.

[50] Hariharan K, Hanna N. Development and application of PROVAX adjuvant formulation for subunit cancer vaccines. Adv Drug Deliv Rev 1998;32:187-97.

[51] Davies DH, McCausland MM, Valdez C, Huynh D, Hernandez JE, $\mathrm{Mu} \mathrm{Y}$, et al. Vaccinia virus H3L envelope protein is a major target of neutralizing antibodies in humans and elicits protection against lethal challenge in mice. J Virol 2005;79:11724-33.

[52] Pietkiewicz H, Hiszczyńska-Sawicka E, Kur J, Petersen E, Nielsen HV, Stankiewicz M, et al. Usefulness of Toxoplasma gondii-specific recombinant antigens in serodiagnosis of human toxoplasmosis. J Clin Microbiol 2004;42:1779-81.

[53] Buxton D, Innes EA. A commercial vaccine for ovine toxoplasmosis. Parasitology 1995;110:11-6.

[54] Kenney RT, Edelman R. DNA vaccines. In: Levine MM, Kaper JB, Rappuoli R, Liu MA, Good MF, editors. New generation vaccines. 3rd ed. New York: Marcel Dekker; 2004. p. 368-70.

[55] Zhou Z, Schnake P, Xiao L, Lal AA. Enhanced expression of a recombinant malaria candidate vaccine in Escherichia coli by codon optimization. Protein Expr Purif 2004;34:87-94.

[56] Lathrop RH, Sazhin A, Sun Y, Steffen N, Irani SS. A multi-queue branch-and-bound algorithm for anytime optimal search with biological applications. Genome Inform Ser Workshop Genome Inform 2001;12:73-82.

[57] Cesbron-Delauw MF, Guy B, Torpier GR, Pierce J, Lenzen G, Cesbron JY, et al. Molecular characterization of a $23 \mathrm{kD}$ major antigen secreted by Toxoplasma gondii. Proc Natl Acad Sci USA 1989;86:7537-41.

[58] Cesbron-Delauw MF. Dense-granule organelles of Toxoplasma gondii. Parasitol Today 1994;10:293-6.

[59] Bhattacharya S, Bunick CG, Chazin WJ. Target selectivity in EF-hand calcium binding proteins. Biochim Biophys Acta 2004;1742:69-79.

[60] Kawasaki H, Nakayama S, Kretsinger RH. Classification and evolution of EF-hand proteins. Biometals 1998;11:277-95.

[61] Bandyopadhyay S, Ghosh SK. Goat testis calmodulin: purification and physicochemical characterization. J Protein Chem 1990;9:603-11.

[62] Tojyo Y, Matsumoto Y. Identification of calmodulin in new-born rat calvaria. Biochem Int 1986;13:155-61.

[63] Seeber F, Beuerle B, Schmidt HH. Cloning and functional expression of the calmodulin gene from Toxoplasma gondii. Mol Biochem Parasitol 1999;99:295-9.

[64] Vogel FR, Hem SL. Immunologic adjuvants. In: Plotkin SA, Orenstein WA, editors. Vaccines. 4th ed. Pennsylvania: Saunders Elsevier Inc; 2004. p. 69-79. 